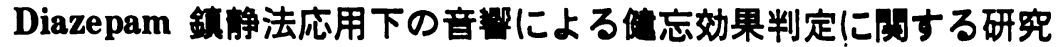

\author{
山崎博嗣・吉沢信夫・星 多見子・野木 湍 \\ 楊井孝・川島康・和田知焳*・鈴木弘造**
}

\section{Amnesia study by auditory sound system under intravenous sedation by diazepam}

\author{
Hirotsugu YamazakI - Nobuo YoshizaWA - Tamiko Hoshi - Mitsuru NogI \\ Takashi YanaI - Yasushi Kawashima - Tomoo WadA* - Kozo Suzuki**
}

\section{粕}

局所麻酶下の口腔内䧽血処置は，患者の立場からみる ときかめて不偷快で，さらには不安，恐怖の対象となる 場合が多く，いわゆる脳筫血様発作等のよらな不快症状 の発現をみることが少なくない，そのため，これら歯科 臨床上問題となる種々の不快症状発現に関する研究は従 来より各方面において行われてきたが22,25,34,36)，当教室 に㨟いては10数年来, 特に循環動態をはじめとする病態 生理を中心に, 吉沢 ${ }^{37)}$, 稲垣 ${ }^{17}$ ), 県1)らの報告をはじめ として，詳細かつ多角的な研究を蛭けてきた，それとと るに, 予知予防法に関する研究の中で, 異常心拍変動を捕 捉することにより不快症状の発現を直前にとらえる签報 装を作製して臨床に応用する一方， diazepam による 㬹脈鎮㬹法によって発作の発現を予防し，いずれる良好 な結果を得ている. 特に静脈鎮静法について述べる, いわゆる脳負血様発作の既往を有する患者58名に対して

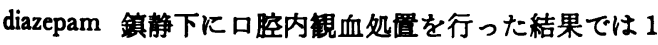
例るいわゆる脳蔶血様発作の発現を認めていない38).

このよらに diazepam 等の minor tranquilizer によ る静脈鎮静法は，齿科口腔外科臨床において有用である ばかりでなく， cardioversion の際に，またその他諸検 查施行時に応用されたり, あるいは耳具科, 産婦人科等

東京菌科大学市川病院科（主任: 川島康教授）

* 東京歯科大学内科（主任: 和田知雄教授）

**東京科大学市川病院内科（主任：鉿木弘造教授） Department of Dentistry, Ichikawa Hospital, Tokyo Dental College (Chief: Prof. Yasushi Kawashima)

* Department of Internal Medicine, Tokyo Dental College (Chief: Prof. Tomoo Wada)

** Department of Internal Medicine, Ichikawa Hospital, Tokyo Dental College (Chief: Prof. Kozo Suzuki)

受付日：昭和53年 7 月 24 日
の臨床各科でも広く応用され良好な結果の得られたこと が報告されている。これは diazepam の静脈内投与によ る鎮觧奻果ばかりでなく，付随する健忘効果を期待して 用いている場合す少なくない，

健忘奻果の臨床的䂓察に関しては文献上，前投薬の䅤 類に闺連する の $5,6,8,21,28,28,29)$ ，全身麻醉に関連する の $2,11,12)$ ，NLA に関連したるの 7 (13,20)，検查施行時その 他がある9,18,31 83). しかしながら diazepam 鎮静法応 用下の口腔内観血処膡時の健忘効果を锶察したるのは比 較的少なく4,14,19,26,27)，さらに詳細な検討を加えていく 必要があるむのと思われる。

また健忘効果の確認方法には，種々のものがあるか， 音管を応用して詳細に追求, 分析したものはこれまでの ところ見当たらない．

今回われわれは, 音䇺法による健忘奻果の確認方法を 考案して diazepam 鎮静法応用下の口腔内観血処膡時に 応用し，臨床的に健忘効果の钼察を行い，若干の知見を 得たので報告する。

\section{研 究 方 法}

\section{1. 对 象}

対象は，東京齿科大学市川病院齿科外来を訪れた者の 5ち，口腔内観血処直を要する19藏から77葴までの男女 75名である。.その内訳は表 1 に示すごとく，既往にいわ ゆる脳負血様発作を呈したことのある者 (HA)27名，高 血圧症を合併している者 (HT)27名，各種の心疾患を合 併している者 (HF) 12名，および智歯抜去を要するも恐 怖心の強い者 (8|8) 9 名である.なお術前の臨床検査の 結果, 重要臟器に重大な障害があると思われる者および 聴覚障害のある者は除外した。

\section{2. 対 照}

対照は，非鎮静下で通法のごとく口膑内観血処置を行 った男女29名である．その内訳は表 2 に示すごとく19歳 から78歳までで, 難聴をはじめ著明な合併症のない者と 
表 1 站 象

\begin{tabular}{|c|c|c|c|c|c|c|c|c|}
\hline 年怢 & t & & & $0-$ & $0 \sim 5$ & $60-69$ & 70 & 31 \\
\hline 娭悡 & & & & & & (1) b? & (1) & | int \\
\hline $\mathrm{H}: \Lambda$ & 0 & 6 & 14 & 1 & 3 & 0 & 0 & 27 \\
\hline $\mathrm{H} \cdot \mathrm{T}$ & 0 & 2 & 1 & 5 & 7 & 9 & 3 & 27 \\
\hline H. F & 0 & 0 & 1 & 3 & 2 & 3 & 3 & 12 \\
\hline $8 \mid 8$ & 1 & 6 & 2 & 0 & 0 & 0 & 0 & 9 \\
\hline if & 1 & 14 & 18 & 12 & 12 & 12 & 6 & 75 \\
\hline
\end{tabular}

表 2 恓 胝

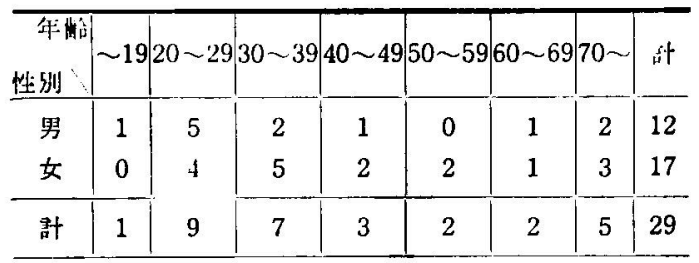

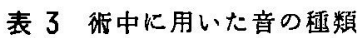

\begin{tabular}{c|c|c}
\hline & 注射後時間 & 音の種類 \\
\hline 1 & 0 秒 & 三味線 \\
2 & 30 秒 & 笛 \\
3 & 1 分 & フヒル \\
4 & 2 分 & 太 䩳 \\
5 & 3 分30秒 & 犬 \\
6 & 5 分 & ニワトリ \\
7 & 6 分30秒 & トランベ・ト \\
8 & 8 分 & ビフル \\
9 & 15 分 & 猫 \\
\hline
\end{tabular}

した。

\section{3. 処置ならびに健忘効果の判定方法}

いわゆる前投楽は使用せず，あらかじめ右前腕皮静脈 に执いて血管の確保を行い，5\%ブド糖等の点滴を持 続し，一律に diazepam $10 \mathrm{mg}$ を管注した。 その時点 からあらかじ用意してあるテープレコーダーにより音 を聞かせた。

音の数は表 ろに示すごとく 9 種類で，楽器の音および 動物の鳴き声とい52つの category から選択し，また 音の大きさは loudness'王) を基準とした， diazepam 管 注後の音を聞かせる時刻は，本研究の前に施行した予備 実験の結果を考慮して決定した， diazepam を投与して 順次音を聞かせるとともに，扣の和のの時点では応答を 確認するように努めた。２分後の太㪗の音と同時に局所 麻醉を開始し，引き続き口腔内観血処置を行った，術後 は bed 上で回復を待ち，1時間を経過して，しかも患者 の帰宅可能な段階で健忘の有無を次の三段階の方法で

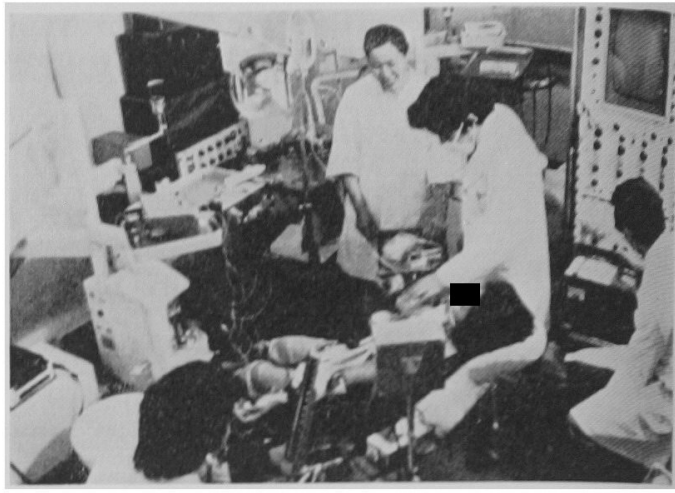

写真 1 街中心情景

$$
\begin{aligned}
& \text { 前投莱圠し } \\
& \downarrow \\
& \text { Diszepam 10mg 管注 } \\
& \text { 手街意 } \\
& \text { 回得 } \\
& \text { 」1患者の自合 } \\
& \text { 磪証 (2)衍者の唀等 } \\
& \text { (3)テープ再生 }
\end{aligned}
$$

図1钼察方法の手順

check した，1．患者の自答すすなわち記憶している音 を㮌不同に答えさせる，2，術者の誘導，すなわら街者 側から音の種類を述べて記憶しているか否かを答えさせ る. 3. テーブ再生, すなからテーブレコーダーより, いくつかの他の音を泿しえながら聞か世記憶しているか 得かを答えさせる。なお本研究で用いたテーブレコーダ

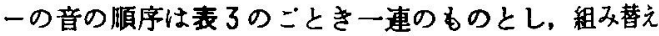
による試験は行わなかった。

術中は，日本光電製多用途監視記録装置 RM-150 b しくは RM-85を使用し，心電龱第 II 誘導，右第 2 指战 上び耳架容積脈波，呼吸，血夜酸素忽和度，脳波，GSR 等により術直前 5 分から術㖟10分に至るまて経時的に病 態生理学的観察を行った（図 1)，写真1 は術中の情景 を示しており，音はイヤホーンを用いず，チェアーサイ

トにあるテーブレコーダーより直接聞かせた。

なお，対照群におい、ては，局所麻酔開始 2 分前より音 を聞かせたのち，約 $1 〜 2$ 時間待機してもらい, 帰宅時 に記憶の有無を確認した。

\section{研 究 成 績}

対照群および対象群ともに既述のごとく三段階で翢査 したが，今回の判定ではテーブ再生を基準にした。 
表 4 対炤群の得血処置内容

\begin{tabular}{|c|c|c|c|}
\hline 具覞 処 & 症 & 例 & 数 \\
\hline 抜 & & 27 & \\
\hline 米 槽 整 形 & & 1 & \\
\hline 骨隆起除去 & & 1 & \\
\hline 計 & & 29 & \\
\hline
\end{tabular}

表 5 対炤群における音の忘却度と症例数

\begin{tabular}{c|c}
\hline 忘却した音の数 & 症 例 数 \\
\hline 0 & 16 \\
$1 \sim 2$ & 11 \\
\hline 3 & 1 \\
5 & 1 \\
\hline
\end{tabular}

1. 対照群 (非鉷軤例) における音の紀憶の有無 の判定

対照29名に対して施行した睍血処置の内容は表 4 のご とくであり，そのほとんどは拔歯であった。術中に不快 症状を呈したすのはなかった.

既述の方法で音を聞かせて確認した結果, 表 5に示す こととく 9 種類の音を忘却することなく全部記憶していた 者は過半数の16名に達した。 また 2 種類以下の音を忘却 した者は11名で, 29名中27名は 2 種類以下の忘却にとど まった。他の 2 名は 3 種類忘却した者（64歳，女），打 よび 5 種類忘却した者 (34歳, 男) の各 1 名であった. さらにこれを释時的に分析してみると図2のごとく，終

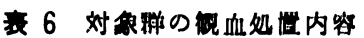

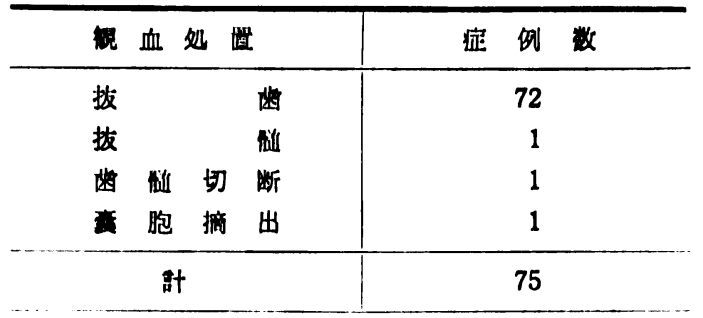

衰 7 対象群に打け万健志奻果 (一) 症例

\begin{tabular}{c|c|c|c}
\hline 症例 & 年路 & 性別 & 圮愤していた音の数 \\
\hline 1 & 72 & 男 & 9 \\
2 & 55 & 男 & 7 \\
3 & 48 & 女 & 9 \\
4 & 40 & 男 & 7 \\
5 & 28 & 男 & 7 \\
6 & 26 & 女 & 8 \\
\hline
\end{tabular}

了に近つくくにつれて音を忘却してしまう傾向が認められ た.

以上の結果より，この方法におけりる音の種類，音を閶 かせる時刻，および音の大きさは健常人にとって，年 龄，性別に関係なくほほ道当で記憶可能な範囲内にある むのと考えられた。

\section{2. 対象群(錤静例) における音の健忘の有無の判定}

対象75名に対して施行した覞血処固は diazepam 鎮静 下に行ったもので表 6 のごとくであり，これもそのはと

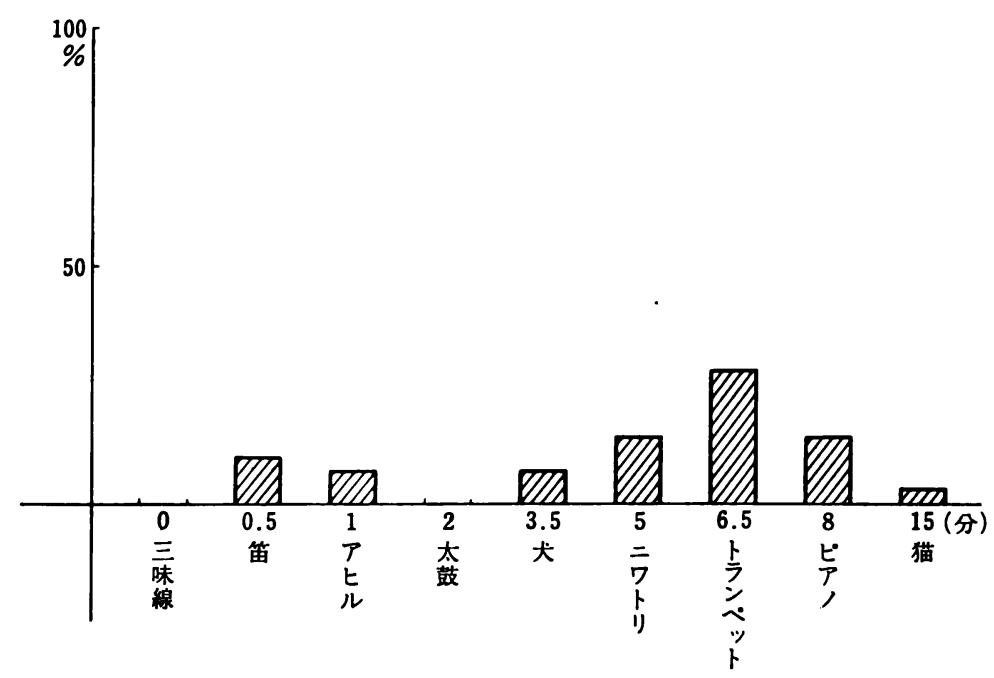

図2释時的にみた対炤群の忘却発現頻度 


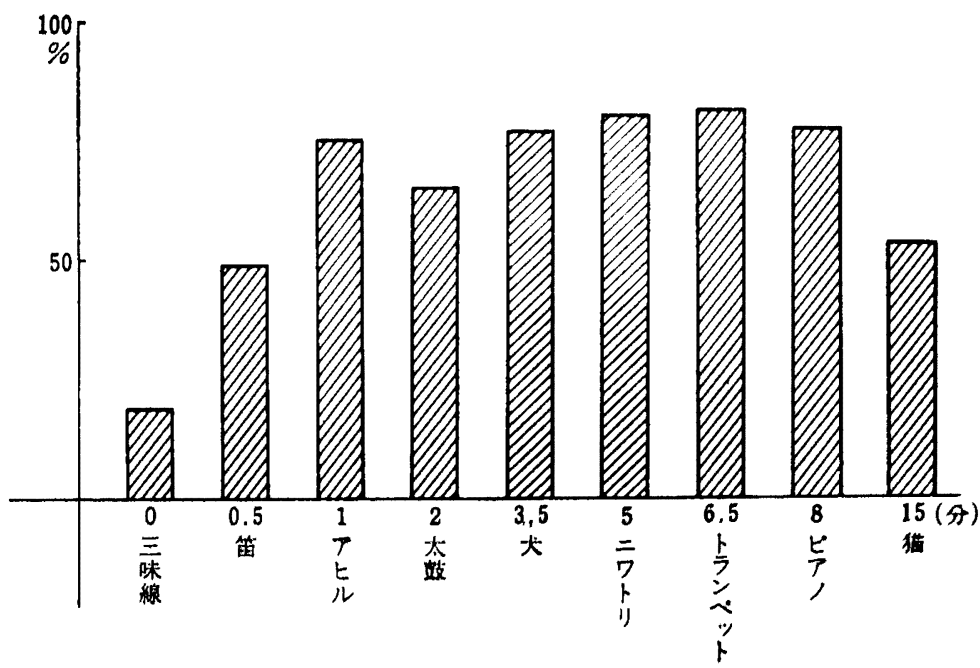

图 3 経時的にみた奶象群の健忘発現频度

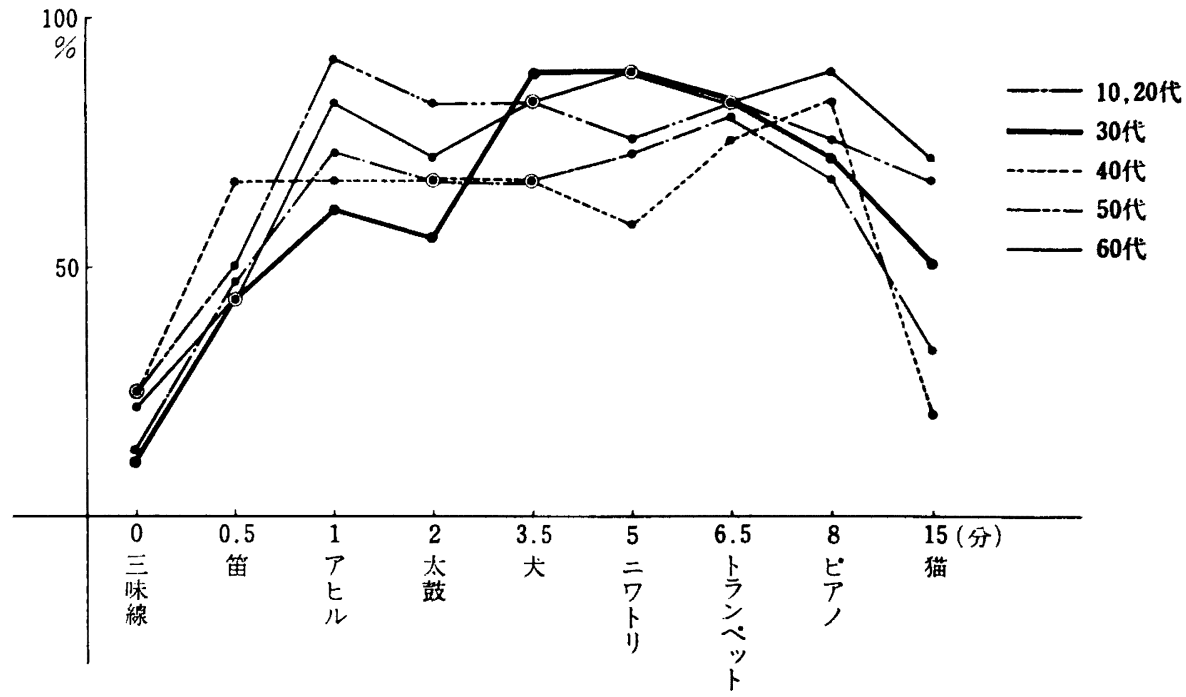

図 4 年龄別の健忘発現頻度とその推移

んどは抜齿であった，平均手術時間は11分 3 秒で，音を 聞かせる時間帯すなわち0〜15分の範囲内であった。な お diazepam 投与後に不快症状を呈した者はなく，また diazepam の追加投与を行った症例もなかった． 対象75 名のらち明らかに健忘効果が認められなかった症例，す なわち diazepam 投与にむかかわらず 9 種類の音のらち 7 種類以上を記憶していた症例は 6 例で, ほとんどの症 例に健忘効果が認められた(表 7)。

\section{3. 健忘の発現頻度とその推移}

図了は対象群の健忘発現頻度とその推移を表わしたも
のである， diazepam 投与後，1 分では75\%，8分で $77 \%$ と高い健忘発現頻度を示したか，15分になると48\% と低下した。すなわち 1 分から 8 分までの健忘発現領度 は高く，15分になると低下していく傾向が認められた。

\section{4. 年跲別にみた健忘の発現頻度とその推移}

図 4 は，健忘の頻度を年跲別にみたるのである.1分 から8分までの健忘発現頻度が比較的高く，15分になる とやや低下していくといら傾向は各年代の間で特に差; なく，またその推移においても著明な差は認められなか った. 


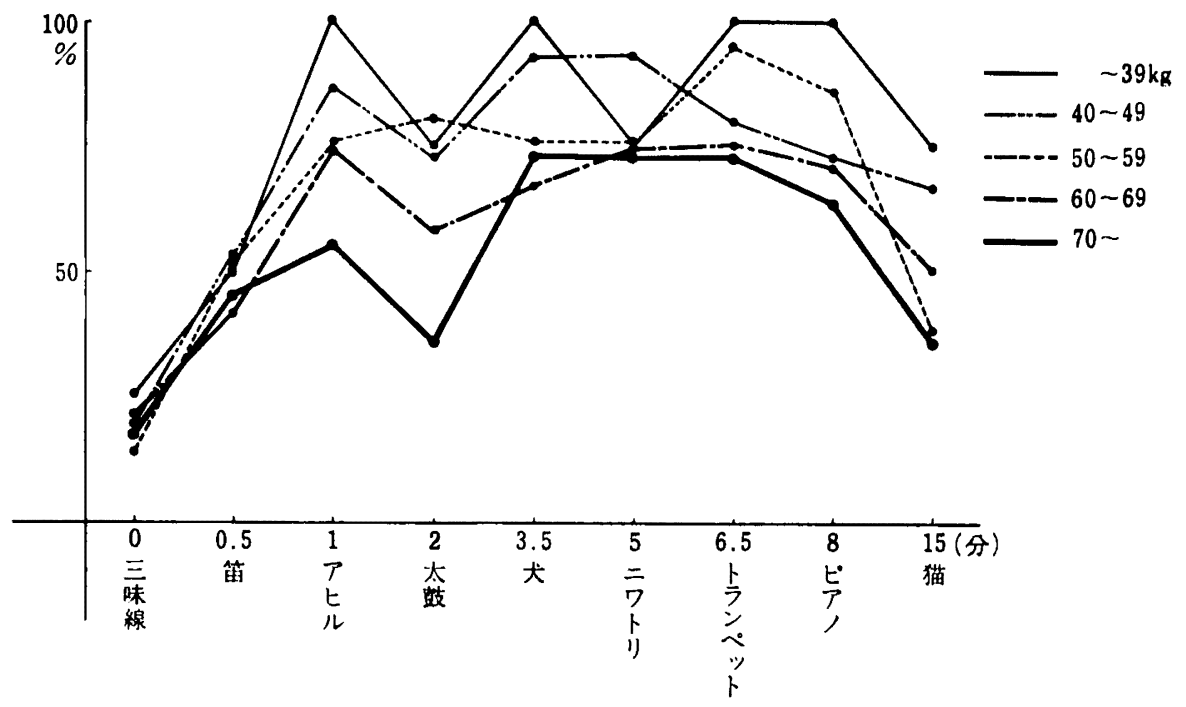

图 5 体重別の健忘袠現影度とその推移

表 8 太鼓および局麻に対する健忘の有無

\begin{tabular}{|c|c|c|c|c|}
\hline & 健 & 忘 & \multirow{2}{*}{ 計 } \\
\hline & & 有 & 無 & \\
\hline 健 & 有 & 25 & 24 & $49\left\{\begin{array}{r}\text { 平均年监 } \\
45 \text { 荗 } \\
\text { 平均体重 } \\
55 \mathrm{~kg}\end{array}\right.$ \\
\hline 忘 & 無 & 13 & 13 & $26\left\{\begin{array}{r}\text { 平均年战令 } \\
44 \text { 歔 } \\
\text { 平均体重 } \\
61 \mathrm{~kg}\end{array}\right.$ \\
\hline \multicolumn{2}{|c|}{ 計 } & $38\left\{\begin{array}{r}\text { 平均年跲 } \\
46 \text { 㹂 } \\
\text { 平均体重 } \\
56 \mathrm{~kg}\end{array}\right.$ & $37\left\{\begin{array}{r}\text { 平均年跲 } \\
43 \text { 歳 } \\
\text { 平均体重 } \\
60 \mathrm{~kg}\end{array}\right.$ & 75 \\
\hline
\end{tabular}

\section{5. 体重別にみた健忘の発現頻度とその推移}

図 5は，健忘の発現頻度を体重別にみたものである.

体重 $39 \mathrm{~kg}$ 以下では，1 分，3 分30秒に 100\% と高い健 忘発現頻度を示した。これに対し，体重 $70 \mathrm{~kg}$ 以上にな ると全般にわたり健忘発現頻度は低く，3 分30秒， 5

分， 6 分30秒での最高時点でも $73 \%$ であった。

\section{6. 局所麻酔開始時点 (太鼓) における健忘発現頻 度の低下}

图 3 および図 5 では，2 分目の時点で健忘発現頻度の 落ち込みが㸾められる。この時点は太鼓の音と同時に局 沂麻酔を開始する時点であり，すなわち聴覚と痛覚に対 する刺激が同時に与えられる時点であるため，いずれの 刖激が健忘発現頻度の落ち込みに関与しているものかを
詳細に検討することにした。

表 8 は，太鼓一局麻開始時点すなわち diazepam 管注 後 2 分目の時点での健忘の有無を示したものである.太 豉の音に対する健忘があり，しかも局所麻酔に対して健 忘のある者は25名で，太鼓の健忘はあるが局所麻酔の健 忘のない者は24名である。また，太鼓の健忘はないが局 所麻酔の健忘のある者は13名で，太鼓，局所麻酔とむに 健忘のない者は13名である。すなわち太鼓の健忘のある 群は合計49名で,太鼓の健忘のない群は合計 26 名であ る. 一方, 局所麻酔に健忘のある群は両群ともほぼ半数 である，すなわち，局所麻酔に対して健忘のある者は38 名で，全症例の $51 \%$ にすぎない，これは，局所麻酔刺激 の与えられた前後の時点, すなわち 1 分および 3 分 30 秒 での聴覚刺激に対する健忘の発現頻度と比較すると明ら かに低く，局所麻蛪開始時の痛覚刺激が大きいことを示 している.

またこの表では，太鼓一局麻に対する健忘のある群お よびない群における平均年秢，平均体重を示している. これをみると，平均年龄において特に差は認められない が, 平均体重では太鼓一局麻に健忘のない群のほらが, 健忘のある群よりやや多くなっている.

さらに図 6 は，太鼓一局麻開始時点での健忘の結果を 基準とした健忘の発現頻度と推移を示している。これを みると，太鼓における健忘のない群（太い実線および点 線）では， 2 分目の太鼓の前後の時点，すなわら 1 分お よび 3 分30秒でも健忘の発現頻度は低く, また全体を通 しても健忘の発現頻度が低い傾向を示している.

以上の結果, 太鼓一局麻開始時点における健忘発現頻 度の低下は，太鼓の音が聴覚刺激として記銘しやすいこ 


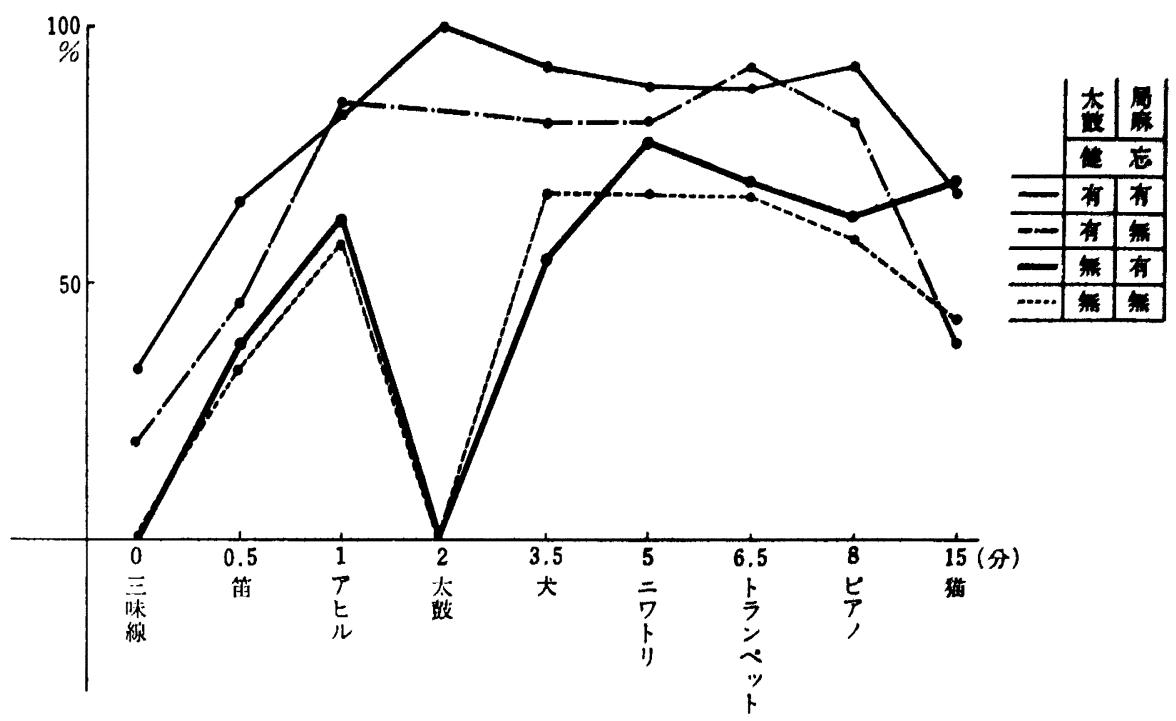

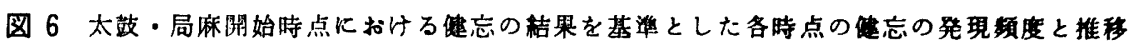

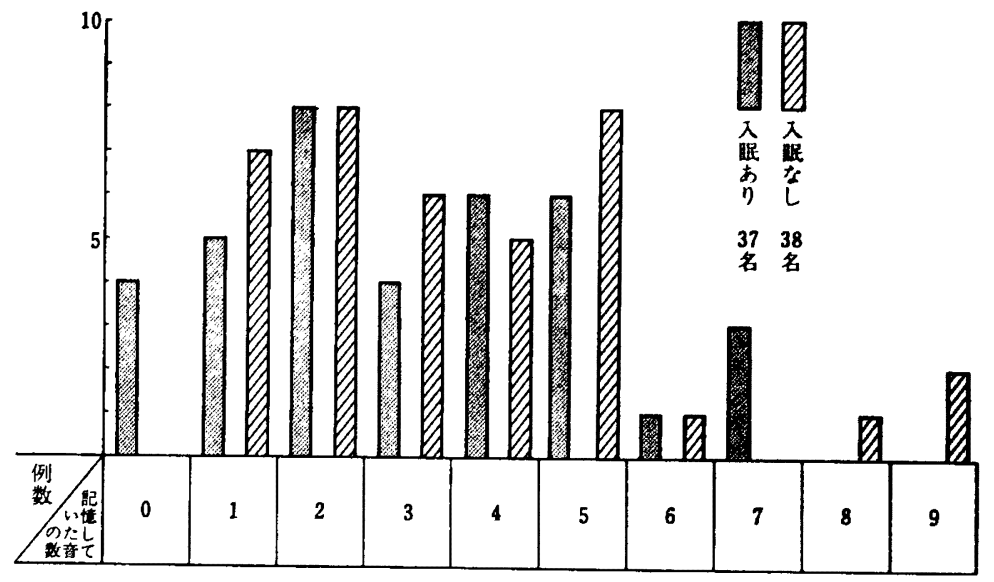

図 7 入眠（術後 1 時間以内）と健忘発現频度との関係

とよりも，局所麻酔による痛覚刺激が大さいことによる ものと思われる。ささらに太鼓一局麻に健忘のない群は平 均体重が多く，体重を基準とした投与量が少なかったこ とに関連するものと思われる.

7. 入眠（術後 1 時間以内）と健忘との関係

術後 1 時間以内に入眠のあった症例は37名, 入眠のな かった症例は38名で, ほぼ同数である。この両群に関し て 9 種類の音の5ち記憶に残った音の数と, その症例数 との関係をみたのが図7である，これによると，術後 1 時間以内の入眠と健忘発現頻度との間には特別な関連が 認められない.

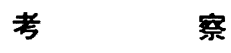

局所麻酔下の口腔内観血処置時に，しばしば発現す名 いわゆる脳負血様発作をはじめとする不快症状に関して は, 従来から多くの研究が行われてきた。しかし，不快 症状の発現防止に関しては，十分な研究が行われてきた とはいいがたい，その中で diazepam 等の minor tranquilizer による静脈鎮静法はきわめて有効な方法として 各方面より高い評価を得ている.

diazepam 鎮静法の臨床的効果としては，1．鎮静效 
果, 2. 健忘奻果, 3. 筋弛嗳作用, 4. 抗痤作用 ${ }^{24)}$ 等 があげられている、崡科口腔外科領㳦における蛙法の 応用に関して，そのおるな目的は思者の口腔内の処倩に 対する不安, 恐怖感をやわらげ，各種不快症状の発現を 防止することであるが，できうれば処溉そのむのの不快 な印象を消去して，術後における患者の科的処政に対 する自信を増強することが望ましい，そのため，健忘奻 果は見落とすことのできない作用の1つである.

しかしながら，健忘の判定があくまで患者の主钼に侬 存する性質のむのであるために，その奻果を碓認する方 法は従来邀切なるのがなく， diazepam 鎮棦法応用下の 健忘効果がいかなるのであるかを詳細に追求し、明確 に捕捉し得た研究はこれまでのところ見当たらない，

健忘効果を確認する方法には，絵や色を記憶させる方 法 (Flinn 59), Frumen 5 $5^{10)}$, Gruber $5^{12)}$, Healy $5^{14)}$ ), 言語刺激を記憶させる方法 (Clarke $5^{3}$ ), Eisenberg $5^{7)}$, Gruber $5^{12}$, Healy $5^{14)}$ ), 疼痛刺激 を記憶させる方法 (Gruber $5^{12)}$ ，Healy $5^{14)}$ ) 等があ るが, われわれは音霜による方法を考案, 応用した。本 法は聴覚を利用するため術中に開眼する必要がく，入 眠時でなければ常に開放されている利点がある。また聴 覚は，他の感覚より麻酔等の施行時にあ抑制されがたい 特徵があることが知られている15).

われわれの音整を用いた健忘効果の確認方法は楽器の 音および動物の鳴き声といら 2つの category から選択 して category 的群化 ${ }^{35)}$ を困り，テープレューダーに録 音した。したがって日常の診療室では容易に聞き得ない 音であると同時に，容易に記憶できるように配虑した。 音の種類は 9 種類で, 三味線, 笛, アヒル, 太鼓, 犬, ニワトリ，トランベット．ピアノおよび猫とし，一定の 時間間隔を拈いて患者に聞かせた。これらの音㽪の種類 は単純で普遍的な刺激のため，個人差によるハラッキは わずかであるるのと思われた，以上のような方法を対照 群に応用した結果，ほほ無理のないものと考えられた。 なお，健忘には逆向性健忘と前向性健忘とがあるか， diazepam の場合は, 多くの報告で, 逆行性健忘を生じ ないとされている3,4,19,27). そこで本研究では前向性健 忘について検討を加えることにした。

一方，静脈鎮静法における diazepam の投与量は局所 麻酷下の歯科処置に際して0.2mg/ $\mathrm{kg}$ 前後で使用される 晹合が多く3,6,14,23,27,29,33)，本研究では体重を測定した 5えで一律に10mg を投与することにした，今回の対象 となった患者の中で最低体重は $39 \mathrm{~kg}$, 最高体重は $76 \mathrm{~kg}$ であった。 これを換算すると0.13mg $/ \mathrm{kg} か ら 0.26 \mathrm{mg} / \mathrm{kg}$ となり，過量投与にはなっていないるのと思われた。

diazepam の投与方法は, あらかじめ確保された静脈 から $5 \%$ ブドウ糖等による点滴を持続し，その点滴を止 めて管注を行い, 点滴を再開するようにした。このため， 管注速度による種々の影響はほぼ一定となるるのと思わ
れた

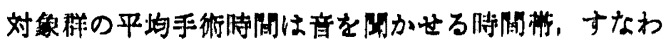
ち0〜15分の筑罒であった。

今回の研究では暗整に刘する健忘の確鯰力法の三段階

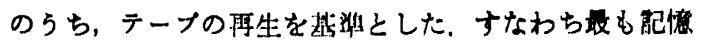
を呼び起こしゃすい状沉で健忘奻果の確袐を行った。

健忘妁果の碓涊㭙期は，O'Neil ら² によると，当日 の回復時および 5 ～ 7 日後の抜糸時である，Driscoll ら4によると，1時間以内および 1 週間後に，Healy ら る.

毁憶に成しては，記銘直後よりもしばらく時间を経て からのは5が一居多くの内容が再生されてくる场合が多 い(reminiscence 現象). この理由として, 記銘の直後 には形成されたばかりの痕跡が互いに抑制し合らために 再生されにくいが，ある程度の時間が経過してその抑制 が止んたのちには比較的再生が容易になる ${ }^{30}$ と説明され ている、このことは，今回の実験における非鎮静下の対 照群における忘却の頻度に関連しているかるしれない. たたしこの reminiscence 現象が，どういう刺滶材料に ついて，またどらいら人に起こりやすいか，その生起す る時期は記銘後どれくらいの時期を経た時，どらなるか 等について種々検討されたものの，一定の結論を導き出 すまでには至っていない30).今回われわれの研究におけ る健忘効果の確認時期は, 手術後䄪 $1 \sim 2$ 時間の安静を 保ったのち帰宅可能となった時点とした. すなわち, 手 術当日に健忘効果の確認を行い, それ以降は行わなかっ た。

健忘効果の有無の判定に関しては，9種類の音のう ち， 7 種類以上を記憶していた者を健忘効果の認められ ない者として規定した。 その結果, 今回の対象のうち明 らかに健忘効果が認められないと判定された症例は全体 の $8 \%$ にすぎず, $92 \%$ に健忘効果が認められた. 文献上， 並木ら ${ }^{23)}$ の報告では diazepam 平均 $0.25 \mathrm{mg} / \mathrm{kg}$ の静脈 内投与で27例中25例に健忘効果を認めている.また，小 岩ら 20 の報告では95\%の症例に健忘効果を認め，Keilty ら ${ }^{19)}$ の報告でも94 95\%の高い率で健忘効果を認めてい る. しかしながら、これらの報告はいずれる刺激の方法 が異なり, 健忘の有無に関する判定の方法る精確でない ため, その結果について単純に比較することは適切と思 われない，しかも，崡科口腔外科領域における処置の内 容, 処置の時間に適合する方法であるためにはわれわれ の音翠による方法のごとく，経時的にかつ短時間に区切 って追求する必要があると思われる.

健忘の持続時間に関して Dundee $ら^{6)}$ は, diazepam $10 \mathrm{mg}$ の静注で 2 分から 4 分までが最も強く, その後は 低下するが10分までは半数にその効果が認められること を示している. Flinn ら9) は平均24分, Clarke ら3は, $0.24 \mathrm{mg} / \mathrm{kg}$ の静注で投与後 10 分までに強い効果が認め 
られ，その啳は娍弱するが約30分まで持続すると述べて いる、また Healy ら 憶の有無は，その内容によって貿なる，たと光ば0.2mg /kg の投与の下で絵をみせる視觉による㒎忘效果碓䟧方 法では平均15分で，筬筒な文を使った会話による场合の 平均25分よりも短かかったとしている，われわれの音都 に上る方法では，1分から8分までの健忘発現顈度は高 く，15分になると䄪半数に低下していく㑯向が䀔められ た.

位忘の発現頻度を年的别にみた結果では，各年代の閌 に特に差を䀔めなかった.この点に四しては Lambrechts

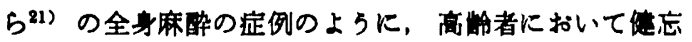
の持綂時间が長いといら現象む㥸められなかった。

健忘の発現頻度を体而別に比较したものでは，体亚を 基滥とした投与貫における来效の差が現われていた。 す なわち diazepam の投与盘を一定とする今回の方法に上 ると，体重の少ない症例に著明な健忘她果が発現してい た. したがって健忘奻果に网してむ，投与量の過少が影 整するむのと思われた。

局所麻䣲開始時点（太鼓）における健忘発現頻度の低 下に関しては，太鼓の健忘のある群と，ない群に分け， 局所麻酔に対する健忘の有無を調查したところ, 局所麻 酔に健忘のない群は，75症例のらち約半数の症例を占め ており，局所麻酔刺激がかなり大きいすのであると思わ れた. すなわち，われわれの音部による健忘効果の確認 方法では，聴覚の刺激が局所麻酔注射に伴う痛覚刺激に よって障害されたものと思われる。ささらに，太敨一局麻開 始時点を基準とした健志の頻度と推移をみると, 太鼓に おける健忘のない群では, 全体を通して健忘の発現頻度 は低く，平均体重においてやや高い数字を示していた。 並木ら 23 は，健忘症が生じなかった症例は， diazepam の量も少なく，また術中に絶えず術者からの発声の協力 を求められたため刺制が多かったことによるとしている が，われわれの音䇺による方法でも同様で, 局所麻酔開 始時点 (太豉) における健忘発現頻度の低下の原因は, 痛覚刺激が聴覚刺激よりも強かったことと，体重を基準 とした場合の投与量よりあ少なかったことに基づくもの と思われる，また太鼓の音か，ある症例にとっては記銘 しやすい刺激であったことも考えられる.

記憶過程において保持を良好にするためには刺激の記 銘後, 何むしないことすなわち入眠がその効果をあげ $ろ^{30)}$ とされている，そこで， diazepam 镇法伈用下の 観血処㯰後から健忘効果確認に至るまでの期間の入眠の 有無と健忘との関係を検討した。 その結果, 術後 1 時間 以内の入眠のあった症例となかった症例はほぼ同数であ り，その健忘発現頻度にも著明な差は認められず，術後 1 時間以内の入眠と健忘発現頻度との間には特別な関連 が認められなかった。すなわち, 術後 1 時間以内に入眠 のあった症例が記憶の保持にすぐれ，健忘の頻度が低い
といろ倾向はなく，われわれの音法による限り，彷货

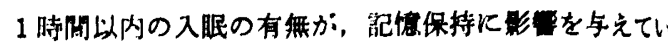
ないよろに思われた。

\section{結}

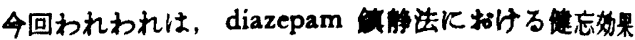

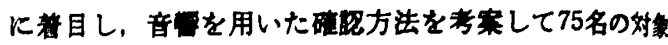
に沁用した結来，次のことき結論を㣞た。

1. 䁃光を利用する方法は，安全で碓实性にすみ，か

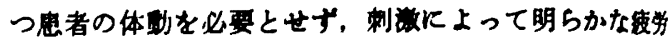
を生ナ゙ることもなかった。

2. 音蒠用いたわれわれの方法は，健忘の短時間内

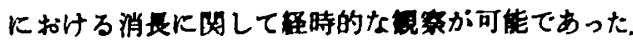

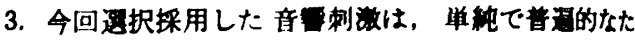
め個人差に上るパラッキは佔少であった。

4. 明らかな健忌奻果は，75名中 69 名に既められた。

5. 健志奶果の無現頻度は， diazepam 投与绻 1 分加 8 分の間において高く，15分後でるその协果は存して いた，すなわち，10分以内に手術を完了することにより 術中の苦痛感は忘却されらると考えられた。

6. 術中の局所麻酥による痛覚刺激は，健忘奻果下影 整を与えた。

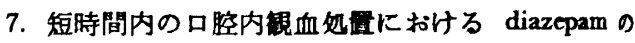
投与量として $0.2 \mathrm{mg} / \mathrm{kg}$ は健忘效果に関してる妥当て あると思われた。

8. 健忘奻果と年路との明らかな成莗性は認められな かった.

9. diazepam 投与による術後 1 時間以内の入眠は侓忘 効果に影部を及ぼさないるのと思われた。

本詥交の要旨は，第 3 回日本四科麻醉学会会会，第22 回日本口腔外科学会総会において甡表した。

\section{引用文献}

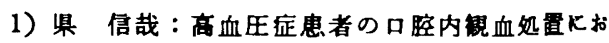

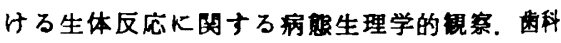
学報, 74: 9511974.

2) Brown, S.S. et al.: Clinical studies of induction agent XXV: Diazepam. Brit J Anaesth 40: 1081968.

3) Clarke, R.P.F., et al.: The amnesic effect of Diazepam (Valium) Brit $\mathrm{J}$ Anaesth 42: 6901970.

4) Driscoll, E. J., et al. Sedation with intravenous diazepam. J Oral Surg 30: 3321972.

5) Dundee, J.W., et al.: Studies of drugs given before anaesthesia XX: Diazepam-containing mixture. Brit J Anaesth 42: 1431970. 
6) Dundee, J.W., et al.: Anterograde amnesic effect of pethidine, hyoscine and diazepam in adults. 5th World Congress of Anesthesiolgists : 961972.

7) Eisenberg, L., et al.: Memory under Diazepam-Morphine neuroleptanesthesia in male surgical patients Anesth. Analg 53:488 1974.

8) Feldman, S.A., et al.: A comparative study of four premidicants. Anaesthesia 18: 169 1963.

9) Flinn, J.F., et al.: Duration of amnesia during sedation with diazepam and pentazocine: preliminary report. J Oral Surg 33: 23 1975.

10) Frumen, J.J., et al.: The amnesic effect of diazepam. 4 th International Congress on Pharmacology, 1969, p 289.

11) Fox, G.S., et al.: A clinical comparison of diazepam and thiopentone as induction agent. Canad. Anaesth Soc J 15: 2811968.

12) Gruber, R.P., et al.: Post operative anterograde amnesia. Brit $\mathrm{J}$ Anaesth 40: 845 1968.

13) Hardy, T.K., et al.: The amnesic properties of hyoscine and atropine in pre-anaesthetic medication. Anaesthesia 17: 3311962

14) Healy, T.E. J., et al.: Interdisciplinary study of diazepam sedation for outpatient dentistry. Brit Med J 3: 131970.

15）逸見 稔：無痡期麻酔の久点とその対策。麻 䣲 12: 4741963.

16) Henri Pieron: La sensation. 島崎敏樹，曹田三 郎（共訳）感覚. 白水社, 東京, 1974, 94頁.

17）稲垣一臣：いわゆる脳貧血様発作の発現要因な らびに生体反応に成する研究。齿科学報 73: 17531973.

18) Kahler, R.L., et al.: Diazepam-Induced Amnesia for cardioversion. JAMA 200: 189 1967.

19) Keilty, S.R., et al.: Sedation for conservative dentistry. Brit J Clin Pract 23: 3651969.

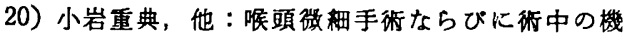
能的榆索に適応した麻醉一NLA 変法と doxapram一一。麻酔 XXV: 13441976.

21) Lambrechts, W., et al.: Post operative amn- esia. Brit J Anaesth 33: 3941961.

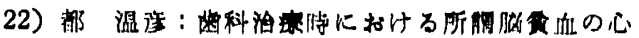

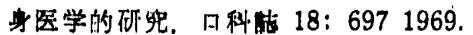

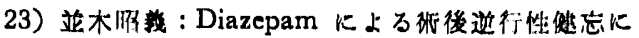
ついて. NLA 研宛 2: 451973.

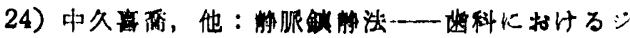

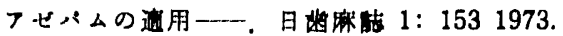

25）大目 事: Dental Shock の発生機序ならひに

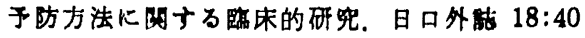
1972.

26）具津桃子，他：科的不安除去—Diazepam の脆服投与一。 日外誌 18:674 1972.

27) O'Neil, $R$. et al.: Intravenous diazepam in minor oral surgery. Brit Dent $\mathrm{J}$ 128: 12 1970.

28) Pandit, S.K., et al.: Pre-operative amnesia, The incidence following the intramuscular injection of commonly used premedicants. Anaesthesia 126: 4211971.

29) Pandit, S.K., et al.: Amnesia studies with intravenous premedication. Anaesthesia 126: 1971.

30）相良守次：記憶とは何か, 岩波毒店, 東京, 1968, 82, 99頁.

31) Shane, S.M., et al.: Intravenous amnesia for total dentistry in one sitting. J Oral Surgery 24: 271966.

32）島田康弘，他：ICU におけ万鎮痛 - 鎮静薬使 用の 1 方法—I I メベシシン・ベンタ・シン ・ジフゼハムの組み合せについて一。麻蠤 XX VI : 1941977.

33）滝沢利明：脳外科項城の检査時麻醉法の新しい 試子。新薬と治瘦 No 173：14 1973.

34）内田安信：齿科愁訴および口腔外科手行と自律 神経機能。口科誌 17:398 1968.

35）八木 笔, 梅本㝒夫：心理学 7. 記億. 東京 大学出版会, 東京, 1974, 76頁.

36) 安井茪：药科口腔外科施街時における頭部血 流動態に関する研究。日口外誌 22：1461976.

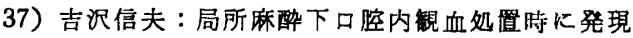
する不快症状の病態生理学的研究。菌科学報 73: 8691973.

38）吉讯信夫：いわゆる脳䨘血栚発作について，歯 科時報 32：34 1978 . 